\title{
DEBUTS
}

Marijke Bassani*

m.l.bassani@hotmail.com

University of New South Wales

Law School

Building F8, Union Road

UNSW Kensington Campus

UNSW Sydney NSW 2052, Australia

\section{International Cultural Heritage Law and World Heritage Listing: A Vehicle for "White Control of Indigenous Heritage"?}

\begin{abstract}
This article demonstrates that the current international cultural heritage protection framework, particularly in relation to the World Heritage List, provides an insufficient legal framework within which to protect Indigenous heritage, both tangible and intangible. This inadequacy is largely attributed to the incompatibility of "cultural heritage" with "Indigenous heritage". An analysis of two dual-listed World Heritage sites - Uluru-Kata Tjuta National Park and Tongariro National Park - reveals that their listing results in an international cultural heritage protection paradigm that is overly bureaucratized and endorses a European colonial State-centric perspective. It thus not only fails to adequately account for Indigenous understandings of cultural heritage, but provides protection that is, at best, piecemeal and inconsistent with the 1976 International Covenant on Economic, Social and Cultural Rights and the 2007 United
\end{abstract}

\footnotetext{
* A Lama Lama and Binthi Warra woman from Cooktown, Cape York in Far North Queensland, Australia, Marijke Bassani graduated with a combined Bachelor of Laws and Bachelor of Politics and Government from Griffith University in 2013. Marijke completed a Master of Laws specializing in International Law at the University of New South Wales (UNSW) in February 2017. She has been awarded a host of scholarships and awards, most recently receiving the Masters Excellence Award at UNSW. Marijke has practiced as a Solicitor in Commercial Litigation, Insurance, Personal and Property Liability and Native Title. Marijke aspires to continue to practice law while pursuing an academic career in International Law.
} 


\section{DEBUTS}

Marijke Bassani

Nations Declaration on the Rights of Indigenous Peoples. The rights and interests of States, tourism industries, and landowners in relation to the heritage listed are often privileged, and this has negative implications for Indigenous peoples whose rights, interests, identities, histories, practices, and knowledge systems are further marginalized during the very process by which States seek to "protect" their heritage.

Keywords: World Heritage, indigenous, human rights, cultural heritage, Indigenous heritage

\section{Introduction}

While the push over the last three decades to protect the intangible and tangible aspects of cultural heritage indicates a growing recognition of cultural diversity, the current international cultural heritage protection framework continues to draw a distinction between the two - resulting in different standards of protection for the tangible and intangible elements of a particular heritage. ${ }^{1}$ This article demonstrates that often the separation of both aspects of cultural heritage constitutes an artificial and arbitrary distinction, since the intangible significance of heritage informs its tangible significance. ${ }^{2}$ This inextricable connection between both elements of cultural heritage is exemplified by the concept of "Indigenous heritage", which recognizes that land, resources, and cultural expressions - including traditional knowledge, language, art, and dance - are constitutive elements that lie at the very core of Indigenous identity. ${ }^{3}$ Together these elements form the foundation of Indigenous heritage and are integral to the cultural survival of Indigenous peoples. ${ }^{4}$ However, the current international cultural heritage protection paradigm, particularly in relation to the World Heritage List (WHL), provides an insufficient legal framework within which to protect Indigenous heritage, both tangible and intangible.

\footnotetext{
1 See especially A. Yupsanis, Cultural Property Aspects in International Law: The Case of the (Still) Inadequate Safeguarding of Indigenous Peoples' (Tangible) Cultural Heritage, "Netherlands International Law Review" 2011, Vol. 58(3), pp. 335, 337; see also W. Logan, Cultural Diversity, Cultural Heritage and Human Rights: Towards Heritage Management as Human Rights-Based Cultural Practice, "International Journal of Heritage Studies" 2012, Vol. 18(3), pp. 231, 235.

2 J. Blake, International Cultural Heritage Law, Oxford University Press, Oxford 2015, p. 150.

3 K. Carpenter, S. Katyal, A. Riley, In Defense of Property, "Yale Law Journal” 2009, Vol. 118(5), pp. 1022, 1028.

4 Ibidem. See generally United Nations Permanent Forum on Indigenous Issues, Who Are Indigenous Peoples? Fact Sheet No. 3, 1, pp. 1-2.
} 
It is argued herein that this inadequacy can be attributed to the incompatibility of "cultural heritage" with "Indigenous heritage", which is due to a number of reasons. ${ }^{5}$ First, international cultural heritage law still struggles to reconcile the tangible and intangible aspects of heritage, resulting in a framework that reinforces a European colonial State-centric view ${ }^{6}$ and that prioritizes the "natural" values and tangible dimensions of heritage over its "cultural" values and intangible dimensions. ${ }^{7}$ Second, States are responsible for nominating and designating heritage for inscription on the WHL, and thus remain in control of what is deemed worthy of protection, including the selection of the values proposed for the specific heritage. ${ }^{8}$ While on the surface this may not appear to be an issue, it is actually problematic, as States often adopt a Euro-centric colonial orientation - privileging the rights and interests of the State, tourism industries, and landowners - which leaves little or no margin for the effective participation of Indigenous peoples in protecting, controlling, and managing their heritage. ${ }^{9}$ Therefore, the question that this article will examine is whether, and if so to what extent and in what manner, inscription on the WHL affects Indigenous rights, identities, practices, and knowledge systems, including Indigenous control and management of cultural heritage.

In seeking to answer this question, this article is divided into three parts. The first part discusses the role of cultural heritage in constructing cultural identity, particularly in relation to Indigenous peoples. This involves examining the incompatibility of "cultural heritage" with "Indigenous heritage", including the tensions that emerge between the characterization of heritage as "universal", "national", "local", or "Indigenous". Part two then examines those human rights which relate to cultural rights set out under international instruments, with specific reference to the International Covenant on Economic, Social and Cultural Rights (ICESCR), ${ }^{10}$ and the United Nations Declaration on the Rights of Indigenous Peoples (UNDRIP). ${ }^{11}$ Although UNDRIP is not a legally binding instrument, like other United Nations "soft law" it has the potential to influence domestic law and policy

5 A. Yupsanis, op. cit., p. 337.

6 See e.g. R. Harrison (ed.), Understanding the Politics of Heritage, Manchester University Press, Manchester 2009, p. 238; see especially T. Winter, Beyond Eurocentrism? Heritage Conservation and the Politics of Difference, "International Journal of Heritage Studies" 2014, Vol. 20(2), pp. 123-125, 132-133; see generally J. Harrington, "Being Here": Heritage, Belonging and Place Making: A Study of Community and Identity Formation at Avebury (England), Magnetic Island (Australia) and Ayutthaya (Thailand) [Ph.D. diss.], James Cook University 2004; see also M. Battiste, J.Y. Henderson (eds.), Protecting Indigenous Knowledge and Heritage: A Global Challenge, Purich Publishing Ltd, Saskatoon 2000, pp. 59-72.

7 J. Blake, op. cit., pp. 20, 152.

8 B. Barreiro Carril, Indigenous Peoples' Participation in Decision-Making in the Context of World Heritage Sites: How International Human Rights Law Can Help?, "The Historic Environment: Policy \& Practice" 2016, Vol. 7(2-3), pp. 224, 227.

9 A. Yupsanis, op. cit., p. 354.

1016 December 1966, 993 UNTS 3.

11 13 September 2007, UN Doc. A/RES/61/295. 


\section{DEBUTS}

Marijke Bassani

over time. ${ }^{12}$ Since space does not permit a detailed analysis of both instruments, an examination will only be made of Articles 3 (right to self-determination), 18 (right to participate in decision making), and 31 (rights in relation to cultural heritage) of the UNDRIP, including Article 15 (right to culture) of the ICESCR. ${ }^{13}$ These articles are significant as they bear on the development of Indigenous heritage legislation, and together provide an effective tool in advocating a human rights-based approach to the protection of Indigenous heritage from the consequences of international cultural heritage practices. ${ }^{14}$

Finally, part three of the article examines two WHL sites - Uluru-Kata Tjuta National Park and Tongariro National Park - to illustrate how the current international cultural heritage protection paradigm is overly bureaucratized and endorses a European colonial State-centric perspective. ${ }^{15}$ This approach not only fails to adequately account for Indigenous understandings of cultural heritage, but provides protection that is, at best, piecemeal, and thus inconsistent with the ICESCR and UNDRIP. ${ }^{16}$ This reading is strongly based on the work of scholars within Critical Heritage Studies ${ }^{17}$ (CHS), namely Melissa Baird, ${ }^{18}$ Laurajane Smith, ${ }^{19}$ Conal McCarthy, ${ }^{20}$ and Jeffrey Sissons. ${ }^{21}$ These two cases have been specifically selected as both sites were among the first in the world to be dual-listed by the United Nations Educational Scientific and Cultural Organization (UNESCO) for outstanding natural and cultural values. ${ }^{22}$ Since both sites were initially inscribed for their natural values only, this article will - through a CHS lens - elucidate how the initial absence and later delay in recognizing their cultural values effectively silences the colonial history of the heritage. ${ }^{23}$

12 J. Hunt, NSW Cultural Heritage Reform: Does the Proposed Model Reflect the United Nations Declaration on the Rights of Indigenous Peoples?, "Indigenous Law Bulletin" 2014, Vol. 8(10), p. 15.

13 Ibidem.

14 J. Fraser, Cultural Heritage in Transit: Intangible Rights as Human Rights, "Human Rights Quarterly" 2015, Vol. 37(2), pp. 556, 560-561.

15 J. Blake, op. cit., p. 20.

16 Ibidem.

17 M. Baird, 'The Breath of the Mountain Is My Heart': Indigenous Cultural Landscapes and the Politics of Heritage, "International Journal of Heritage Studies" 2012, Vol. 19(4), pp. 327, 328-331.

18 Eadem, The Politics of Place: Heritage, Identity, and the Epistemologies of Cultural Landscapes [Ph.D. diss.], University of Oregon 2009.

19 L. Smith, The Uses of Heritage, Routledge, London 2006.

20 C. McCarthy, Museums and Māori: Heritage Professionals, Indigenous Collections, Current Practice, Left Coast Press, Wellington 2011.

21 J. Sissons, First Peoples: Indigenous Cultures and Their Futures, Reaktion Press, London 2005.

22 See e.g. J. Jokilehto, Human Rights and Cultural Heritage. Observations on the Recognition of Human Rights in the International Doctrine, "International Journal of Heritage Studies" 2012, Vol. 18(3), pp. 226, 229; see especially R. Hill et al., Empowering Indigenous Peoples' Biocultural Diversity Through World Heritage Cultural Landscapes: A Case Study from the Australian Humid Tropical Forests, "International Journal of Heritage Studies" 2011, Vol. 17(6), pp. 571, 572.

23 M. Baird, 'The Breath..., p. 327. 
Taking the above into account, this article proposes applying a human rightsbased approach to the WHL decision-making process. This will assist in deconstructing the colonial structures which remain as hidden dimensions embedded within international cultural heritage law, and will ensure that the identification, inscription, and management of Indigenous heritage is Indigenous-driven, and thus consistent with international legal norms protecting Indigenous peoples' rights. ${ }^{24}$

\section{The Role of Cultural Heritage in Constructing Cultural Identity}

While the definitions of "culture" vary, ${ }^{25}$ there is a general consensus among academics that the notion of "culture" is itself dynamic and constantly reinvented, rather than static or inert. ${ }^{26}$ Consequently, according to UNESCO "cultural heritage" refers to both tangible and intangible elements, ranging from architectural works, sculptures and paintings to dance, language, and knowledge. ${ }^{27}$ The relationship between both elements is one of mutuality: intangible heritage often results from an interaction between human societies and tangible elements of heritage, and thus gives the heritage its meaning and significance. ${ }^{28}$

Although theoretically international cultural heritage law recognizes the connection between the tangible and intangible aspects of heritage, and that together they comprise cultural heritage, in practice a distinction between the two continues to exist. ${ }^{29}$ This demarcation is evidenced by UNESCO instruments, including the Convention on the Means of Prohibiting and Preventing the Illicit Import, Export and Transfer of Ownership of Cultural Property, ${ }^{30}$ the 1954 Hague Convention for the Protection of Cultural Property in the Event of Armed Conflict, ${ }^{31}$ the Convention for the Safeguarding of Intangible Cultural Heritage ${ }^{32}$, and the Convention on

24 Ibidem, p. 329; see e.g. B. Barreiro Carril, op. cit., pp. 224-225; see also W. Logan, op. cit., p. 242.

25 See especially Texas A \& M University, Culture, 2016, https://www.tamu.edu/faculty/choudhury/ culture.html [accessed: 31.10.2017]; see generally W. Logan, op. cit., pp. 234-235. For further details on ideational theories of culture, see R. Keesing, Theories of Culture, "Annual Review of Anthropology" 1974, Vol. 3(1), pp. 73, 77-81.

26 See especially J. Fraser, op. cit., p. 556; see generally J. Banks, C. McGee (eds.), Multicultural Education: Issues and Perspectives, Allyn \& Bacon, Boston 1989; see also J. Lederach, Preparing for Peace: Conflict Transformation Across Cultures, Syracuse University Press, Syracuse 1995, p. 9. See generally University of Minnesota. The Center for Advanced Research on Language Acquisition, What is Culture?, 2014, http://carla.umn. edu/culture/definitions.html [accessed: 31.10.2017]. Cf. T. Parsons, Essays in Sociological Theory, Pure and Applied, Free Press, New York 1949.

27 W. Logan, op. cit., p. 238.

28 J. Blake, op. cit., pp. 134-135.

29 Ibidem, pp. 152-153.

3014 November 1970, 823 UNTS 231.

3114 May 1954, 249 UNTS 215.

3217 October 2003, 2368 UNTS 1. 


\section{DEBUTS}

Marijke Bassani

the Protection and Promotion of the Diversity of Cultural Expressions. ${ }^{33}$ This division of the protection of cultural heritage into tangible and intangible elements in UNESCO treaty-making results from the fact that, historically, international cultural heritage law focused on material or rather tangible heritage such as artefacts, art objects, and monuments. ${ }^{34}$ It was not until later that recognition and protection of the intangible aspects of heritage were developed. ${ }^{35}$

The Convention Concerning the Protection of the World Cultural and Natural Heritage ("the 1972 Convention") ${ }^{36}$ contributed to this development when the World Heritage Committee (WHC) introduced the concept of "heritage" by including natural and cultural aspects of heritage within the Convention. ${ }^{37}$ Although the integration of cultural and natural heritage implicitly included intangible elements, ${ }^{38}$ the WHC's failure to explicitly recognize intangible heritage within the scope of the 1972 Convention at the time of its drafting ${ }^{39}$ excluded the idea of treating tangible, intangible, and natural heritage as indivisible elements. ${ }^{40}$ Many Indigenous peoples champion a worldview that such divisions are arbitrary, in that they serve a legislative and operational purpose and fail to reflect the true nature of heritage ${ }^{41}$ which is that human societies and cultures have been largely moulded by their natural environment, which in turn has also been significantly shaped, in a complementary way, by human interactions and activities. ${ }^{42}$ Consequently, "Indigenous heritage" recognizes that these elements - tangible, intangible, cultural, and natural - are inseparable since together they form the foundation of Indigenous identity and are integral to the cultural survival of Indigenous peoples. ${ }^{43}$

Although the $\mathrm{WHC}$ has attempted to reflect this view by revising the Operational Guidelines, evolving the WHL inscription criteria and introducing categories

3320 October 2005, 2240 UNTS 346.

34 J. Blake, op. cit., p. 134.

35 Ibidem.

3616 November 1972, 1037 UNTS 151.

37 J. Blake, op. cit., pp. 117, 128.

38 See e.g. the 2000 revision of the Operational Guidelines to the 1972 Convention, which for the first time recognized "associated intangible values" as an important criterion for selecting a cultural site; see also J. Blake, op. cit., pp. 117, 128.

39 At the time of its drafting some Member States, in particular Bolivia, had requested the inclusion of intangible heritage within the scope of the 1972 Convention (J. Blake, op. cit., p. 128).

40 Ibidem.

41 Ibidem, pp. 128, 129

42 For example, it is now recognized that the wetlands which are subject to the 1971 Ramsar Convention are formed by low-impact human activities (cutting reeds, traditional irrigation systems, etc.) and that these activities must continue in order for the wetland system to remain healthy (see also ibidem, p. 129).

43 M. Baird, 'The Breath..., pp. 333-334; see also K. Carpenter, S. Katyal, A. Riley, op. cit., p. 1028. 
such as "cultural landscapes" 44 and mixed - cultural and natural - sites, ${ }^{45}$ inequities continue to exist for Indigenous peoples in the control, protection, and nomination of their heritage. ${ }^{46}$ For example, new provisions on Indigenous peoples in the 2015 revision of the 1972 Convention's Operational Guidelines makes significant strides towards enhancing Indigenous rights by encouraging States to obtain their free, prior, and informed consent during the nomination process for WHL. ${ }^{47}$ However, in practice the Guidelines are inadequate in that they fail to create obligations for States when it comes to involving Indigenous peoples in the nomination process, including obtaining their full, prior, and informed consent. ${ }^{48}$ Consequently, the provisions provide merely recommended practices rather than a legal obligation, which has the effect of undermining rather than strengthening Indigenous rights in relation to their heritage and identity. ${ }^{49}$

For Indigenous people, the notion of "cultural heritage" includes "everything that belongs to [their] distinct identity [as] a people"50 such as language, music, dance, knowledge systems, and artworks (intangible)..$^{51}$ Inheritances from the past and from nature, such as ancestral remains and traditional lands (tangible) are also included. ${ }^{52}$ This further underlines the inextricable link between culture, heritage, and traditional lands, including how deeply connected cultural and natural heritage is to the construction and preservation of Indigenous identity and the Indigenous worldview more broadly. ${ }^{53}$ It is unsurprising then, that the destruction of cultural heritage often has a profound psychological effect on Indigenous people. ${ }^{54}$ For this reason, Indigenous claims to heritage - including its preservation - conflict with State claims, on both political and economic fronts. ${ }^{55}$

\footnotetext{
44 "Cultural landscapes" were included in the 1992 revision of the Operational Guidelines as a category for inscription on the WHL during the redrafting of the cultural criteria, which was based on work produced in a UNESCO expert meeting held in France in October 1992 (see also J. Blake, op. cit., p. 130).

45 The category of "mixed cultural and natural heritage" was introduced in the 1998 revision of the Operational Guidelines and effectively gave more explicit recognition to the interrelated character of tangible and intangible heritage, including the need for an integrated protection approach. Of the 1,007 properties listed around the world, 779 are cultural, 197 are natural and only 31 are mixed (ibidem, pp. 119, 132, 133).

46 See W. Logan, op. cit., p. 231; see also M. Baird, 'The Breath..., pp. 328, 336.

47 S. Disko, The 39th Session of the World Heritage Committee, in: D. Vinding, C. Mikkelsen (eds.), The Indigenous World 2016, Transaction Publishers, Copenhagen 2016, pp. 519, 520.

48 Ibidem, pp. 520, 521.

49 See W. Logan, op. cit., p. 231; see also M. Baird, 'The Breath..., pp. 328, 336.

50 E.-I. Daes, Protection of the Heritage of Indigenous People, OHCHR, New York 1997.

51 J. Blake, op. cit., p. 134.

52 Ibidem.

53 Ibidem.

54 R. Pepper, S. Duxson, Not Plants or Animals: The Protection of Indigenous Cultural Heritage in NSW, "Judicial Officers Bulletin" 2014, Vol. 26(9), pp. 75, 76.
}

55 W. Logan, op. cit., p. 238. 


\section{DEBUTS}

Marijke Bassani

The preservation of cultural identity is critical to an individual's sense of well-being and respect, hence cultural identity can be said to lie at the heart of human rights itself. ${ }^{56}$ In essence, a right to cultural identity translates into the right to choose one's cultural identity. ${ }^{57}$ This includes the right to preserve, develop, and maintain it, as well as the right not to have an alien culture imposed on one's cultural identity. ${ }^{58}$ Thus, the right to have one's cultural identity respected has increasingly been regarded as fundamentally important to individuals, particularly in terms of the State or community to which they belong. ${ }^{59}$ This is most commonly framed in relation to the rights of cultural minorities and Indigenous people within unitary States. ${ }^{60}$

Here it can be seen that the role of cultural heritage in identity formation occurs at three levels: the individual, community, and the State. ${ }^{61}$ International cultural heritage law operates on the third level, as international law is itself a system built upon the State, and the preservation of a State's cultural identity is crucial to its continuing viability. ${ }^{62}$ Consequently, the cultural heritage of a State and its people - united through shared landscape, history, and experiences - is perceived as constituting the symbolic value of a State's cultural identity, including that of its people. ${ }^{63}$ Yet, as will be discussed below, the complexity of cultural identity and the implications of granting a right to such under international cultural heritage law is illustrated by conflicts between the values underpinning the international protection of cultural heritage and Indigenous claims to heritage. ${ }^{64}$

\section{Conflict between cultural heritage and Indigenous heritage}

The WHL Aboriginal rock art at the Kakadu National Park in Australia provides a good example of such conflicting values and claims, as it bears "universal" value for humankind, while also holding special significance for Indigenous Australians, for whom the art symbolizes their unique cultural identity. ${ }^{65}$ Here we have a conflict between the Indigenous right of access, including the right to keep secret and deny access to the cultural heritage, and the right of all humankind to the equal

\footnotetext{
56 Ibidem.

57 Ibidem.

58 Ibidem.

59 Ibidem.

60 Ibidem.

61 Ibidem.

62 Ibidem, p. 276.

63 Ibidem.

64 J. Blake, op. cit., p. 277.

65 Ibidem, pp. 277-278.
} 
enjoyment and preservation of this heritage. ${ }^{66}$ While UNDRIP attempts to strike a balance in such cases by affirming in its Preamble that "all peoples contribute to the diversity and richness of civilisations and cultures, which constitute the common heritage of humankind", it does so in a way that undermines Indigenous ownership and control over Indigenous heritage. ${ }^{67}$ For example, Article 31(1) of UNDRIP acknowledges the right of Indigenous peoples to maintain, control, protect, and develop their cultural heritage, but fails to recognize their full ownership of it. ${ }^{68}$ This failure to affirm Indigenous ownership is not surprising, as where competing claims to heritage exist, determining who the heritage belongs to is of great significance as the ability to control or define the heritage relates directly to who has the authority to write, or rather rewrite, the history surrounding it. ${ }^{69}$ This demonstrates how the inscription of Indigenous heritage on the WHL often leads to "white control of their heritage". 70

Accordingly, the WHL Kakadu Aboriginal rock art highlights, inter alia, the tensions that arise when determining the characterization of cultural heritage as universal, national, local, or Indigenous heritage. ${ }^{71}$ While international law formally recognizes the cultural diversity of the peoples of the world as "universal" heritage of humankind ${ }^{72}$ and affirms that "each culture has a dignity and value that must be respected and preserved", ${ }^{73}$ tensions become especially prominent with respect to Indigenous heritage claims. ${ }^{74}$ This is because Indigenous heritage claims not only challenge the State's right to own and control such heritage, but also call into question the idea of "universal" or "national" heritage..$^{75}$ In doing so, Indigenous heritage claims implicitly suggest that the notions of "universal" or "national" heritage express a European colonial State-centric worldview, which fails to account for Indigenous understandings of the nature and significance of their cultural heritage. ${ }^{76}$ For example, cultural heritage as a "national" heritage can provide a unifying force, emphasizing the shared identity of a specific State. ${ }^{77}$ However, minorities and

\footnotetext{
66 Ibidem, p. 282.

67 Ibidem.

68 A. Yupsanis, op. cit., p. 360.

69 J. Fraser, op. cit., p. 558.

70 J. Blake, op. cit., pp. 20-22.

71 W. Logan, op. cit., p. 237.

72 UNESCO Universal Declaration on Cultural Diversity, 2 November 2001, UNESCO Doc. 31C/ Res. (2001).

73 UNESCO Declaration on the Principles of International Cultural Cooperation, 16 November 1966 , UNESCO Doc 28 C/Res 5.61 (1966), Article 1.

74 J. Blake, op. cit., p. 20.

75 Ibidem.

76 Ibidem.

77 W. Logan, op. cit., pp. 237-238.
} 


\section{DEBUTS}

Marijke Bassani

Indigenous peoples often struggle to assert their cultural distinctiveness within the culture of the State's dominant majority, and thus experience difficulties in protecting their cultural identities and traditions in the face of homogenizing cultural influences..$^{78}$ This highlights how current colonial histories and structures create obstacles for cultural minorities and Indigenous peoples in asserting their social and political authority over competing claims to their heritage. ${ }^{79}$

According to Lucas Lixinski, "Indigenous heritage and meanings have been constructed by States within a colonial discourse of authorised heritage meanings". ${ }^{80}$ Hence, any "Indigenous cultural claims that fall outside of this authorised discourse tend to be disregarded as irrelevant or illegitimate". ${ }^{11}$ Indeed, in some contexts World Heritage even works to erase the social, cultural, and political environments in which it operates, ${ }^{82}$ because during the process of universalizing and nation-building, Indigenous heritage is redefined and the history of their struggles are decoupled..$^{83}$ Consequently, the colonial histories of a particular Indigenous World Heritage site are presented for an international audience, devoid of the larger political issues concerning Indigenous sovereignty, autonomy, and control of identity. ${ }^{84}$ The socio-political implications and human rights consequences for Indigenous peoples of such a European colonial State-centric orientation will be discussed below.

\section{A Human Rights-based Approach to Heritage Protection}

Although cultural heritage is itself based on the diversity of the individual contributions of humankind, ${ }^{85}$ and encompasses the right of all human beings, including successive generations, to enjoy their heritage, ${ }^{86}$ growing evidence suggests that the inscription of sites to the WHL actually prevents Indigenous peoples from doing just that. ${ }^{87} \mathrm{At}$ issue here is the relationship between human rights concerning cultural rights, and cultural heritage. ${ }^{88}$ While these two elements have historical-

78 Ibidem; see also J. Blake, op. cit., p. 278.

79 See especially M. Baird, 'The Breath..., p. 328; see also J. Blake, op. cit., p. 20.

80 See especially L. Lixinski, Intangible Cultural Heritage in International Law, Oxford University Press, Oxford 2013, p. 24.

81 Ibidem.

82 M. Baird, 'The Breath..., p. 337.

83 Ibidem.

84 Ibidem.

85 UNESCO Universal Declaration on Cultural Diversity, op. cit.

86 UNESCO Declaration on the Principles of International Cultural Cooperation, op. cit., Article 1.

87 J. Jokilehto, op. cit., p. 226.

88 S. Maus, Hand in Hand Against Climate Change: Cultural Human Rights and the Protection of Cultural Heritage, "Cambridge Review of International Affairs" 2014, Vol. 27(4), pp. 699, 708. 
ly been treated as distinct concepts, recognition of the interplay between human rights, cultural rights, and cultural heritage, particularly in relation to Indigenous heritage, is increasing. ${ }^{89}$ However, cultural rights themselves are not without contradictions and inconsistencies..$^{90}$

As has been oft-noted, the rights of individuals have to be balanced with group rights, and cultural rights may conflict with other human rights. ${ }^{91}$ Further compounding this is the fact that cultural rights are often torn between two different but linked meanings. ${ }^{92}$ As a subcategory of human rights, cultural rights are endowed with a universal character, which is a major characteristic and postulate of human rights generally. ${ }^{93}$ Yet the connection between cultural rights and cultural diversity challenges the very idea of universal human rights. ${ }^{94}$ Despite this, combining human rights and heritage discourses to inform a human rightsbased approach to cultural heritage protection provides the current international framework with elements of moral and political responsibility. ${ }^{95}$ In an Indigenous context, a human rights-based approach to protecting and preserving cultural heritage supports Indigenous cultural rights and allows for cultural heritage to be used as a vehicle in strengthening the protection of Indigenous identities, practices, and knowledge systems. ${ }^{96}$

Numerous international human rights instruments ${ }^{97}$ may be of assistance in enhancing the protection of Indigenous cultural rights to cultural heritage, in particular ICESCR and more importantly, UNDRIP. Article 15 of the ICESCR affirms the right of all to take part in cultural life, and since it is universal in character the Committee on Economic, Social and Cultural Rights confirmed in General Comment 21 that this covers the right of Indigenous peoples to act collectively to ensure respect for their right to maintain, control, protect, and develop their cultural heritage. ${ }^{98}$ This includes an obligation on the part of States to respect the principle of free, prior, and informed consent of Indigenous peoples in all matters covered by their specific rights. ${ }^{99}$ Taking this into account, Article 15 of the ICESCR provides

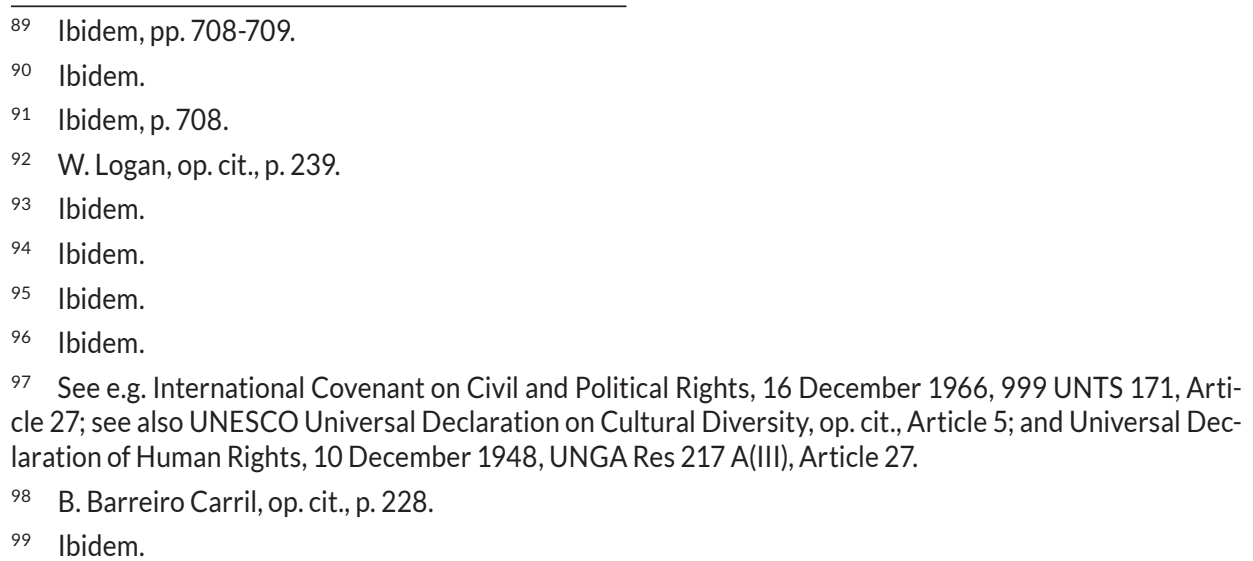




\section{DEBUTS}

Marijke Bassani

a platform for the implicit protection of Indigenous heritage from the inequities that often arise in the process of heritage identification, inscription, and management. ${ }^{100}$ On the other hand Articles 3, 18, and 31 of UNDRIP provide explicit protection for Indigenous peoples' rights, particularly in relation to their heritage. ${ }^{101}$ Together these articles can be used to engage Indigenous peoples in WHL decision-making processes concerning the identification, inscription, management, and protection of Indigenous cultural heritage, as well as in the formation of the WHL criteria against which Indigenous heritage claims are examined. ${ }^{102}$ This would assist in strengthening the protection of Indigenous cultural rights to cultural heritage. ${ }^{103}$

Nevertheless, current international cultural heritage practices fail to engage Indigenous peoples through the use of these articles, instead endorsing a European colonial State-centric view that often results in Indigenous loss of control over, and at times even dispossession of, their heritage. ${ }^{104}$ This was the case with the Endorois people, ${ }^{105}$ a traditional pastoralist community evicted by the Kenyan Government from their traditional lands without either prior consultation or compensation, due to the site's inscription on the WHL. ${ }^{106}$ The case was brought before the African Commission on Human and Peoples' Rights, which found that the right of the Endorois people to develop ${ }^{107}$ had been violated as a result of the State's failure to inform and adequately involve them in the decision-making process. ${ }^{108}$ This finding led to a revision of the UNESCO Operational Guidelines to ensure their consistency with UNDRIP in relation to the protection of Indigenous rights in World Heritage sites. ${ }^{109}$ Despite this, the Guidelines neither impose obligations on States to involve Indigenous peoples in the nomination process, nor to obtain their full, prior, and informed consent. ${ }^{110}$ While the difficulties UNESCO faces in involving all relevant stakeholders in the decision-making process of a site's inscription must not be dismissed, ${ }^{111}$ in this instance the inadequate representation and inclusion of the Endorois peoples in the control of their heritage only highlights the colonial

$100 \quad$ Ibidem, p. 241.

101 Ibidem.

102 Ibidem.

103 Ibidem.

104 J. Fraser, op. cit., p. 561.

105 African Commission on Human and Peoples' Rights, Centre for Minority Rights Development (Kenya) and Minority Rights Group International on behalf of Endorois Welfare Council v. Kenya, Judgment of 25 November 2009.

106 B. Barreiro Carril, op. cit., pp. 230-231.

107 UNDRIP, op. cit., Article 1.

108 B. Barreiro Carril, op. cit., pp. 230-231.

109 Ibidem, p. 231.

110 Ibidem, p. 232. See especially UNESCO Operational Guidelines for the Implementation of the World Heritage Convention, 8 July 2015, UNESCO Doc. WHC.15/01 (2015), paras. 123, 130.

111 B. Barreiro Carril, op. cit., p. 231. 
structures which remain as hidden dimensions embedded within international cultural heritage laws, policies, and practices. ${ }^{112}$ As the following World Heritage sites demonstrate, this has broader implications for Indigenous peoples, whose rights, identities, practices, and knowledge systems are affected as a result. ${ }^{113}$

\section{Critical Heritage Studies Analysis of Two World Heritage Listed Sites}

A CHS analysis of the historical, cultural, and legal contexts of two World Heritage sites - Uluru-Kata Tjuta National Park and Tongariro National Park - illustrates how the current international cultural heritage paradigm is overly bureaucratized, resulting in piecemeal protection of Indigenous heritage which violates international human rights standards, namely Articles 3, 31, and 18 of the UNDRIP, and Article 15 of the ICESCR. ${ }^{114}$ This is attributed to the current framework which, using an European colonial State-centric lens, supports the colonial dimensions of current heritage laws, policies, and practices, which discount Indigenous understandings of cultural heritage. ${ }^{115}$ Developed in the $1990 \mathrm{~s}, \mathrm{CHS}$ is based on the idea that a larger hegemonic discourse elaborates current heritage laws and practices. ${ }^{116} \mathrm{CHS}$ thus examines the power dynamics, including political and social implications, of such practices. ${ }^{117}$

Drawing on the works of Marx, ${ }^{118}$ Habermas, ${ }^{119}$ and Foucalt,,${ }^{120} \mathrm{CHS}$ questions the neutrality of cultural heritage practices by examining how knowledge is produced within colonial relations of power, including how institutionalized heritage narratives preclude diverse actors from identifying and articulating their own heritage concepts, practices, and policies. ${ }^{121}$ In the context of Indigenous rights,

\footnotetext{
112 M. Baird, 'The Breath..., p. 329.

113 Ibidem.

114 T. Chapman, Corroboree Shield: A Comparative Historical Analysis of (The Lack of) International, National and State Level Indigenous Cultural Heritage Protection, "Macquarie Journal of International and Comparative Environmental Law" 2008, Vol. 5(1), p. 81.

115 M. Baird, 'The Breath..., p. 328.

116 Ibidem; see especially US Chapter of the Association of Critical Heritage Studies, Welcome to the US Chapter of ACHS, 2013, http://achsus.umbc.edu [accessed: 31.10.2017].

117 M. Baird, 'The Breath..., p. 328; see especially US Chapter of the Association of Critical Heritage Studies, op. cit.

118 K. Marx, F. Engels, The German Ideology, transl. C.J. Arthur, International Publishers, New York 1970.

119 J. Habermas, Some Question Concerning the Theory of Power: Foucault Again, in: M. Kelly (ed.), Critique and Power: Recasting the Foucault/Habermas Debate, Massachusetts Institute of Technology Press, Cambridge, MA 1994.

120 M. Foucault, The Subject and Power, in: H. Dreyfus, P. Rabinow (eds.), Michel Foucault: Beyond Structuralism and Hermeneutics, University of Chicago Press, Chicago 1983, pp. 208-228.

121 US Chapter of the Association of Critical Heritage Studies, op. cit.
} 


\section{DEBUTS}

Marijke Bassani

the CHS approach questions common assumptions and "truths" about Indigenous history, and points to interactions as signs of resistance, appropriation, reinterpretation, and adaptation. ${ }^{122}$ Therefore, the CHS approach is applicable in the context of this article, as it creates space for understanding how Indigenous peoples are engaged in negotiating, identifying, and managing their heritage. ${ }^{123}$

\section{Uluru-Kata Tjuta National Park}

The Uluru-Kata Tjuta National Park, located in the Central Australian desert, had its title returned to the traditional owners, the Anangu people, by the Australian Federal Government in 1985.124 The Anangu people, in turn, "granted" the Australian National Parks and Wildlife Service a 99-year lease allowing for the Park to be jointly managed by both. ${ }^{125}$ The Park was first inscribed on the WHL in 1987 under the criteria of natural heritage, but in 1994, in response to Anangu calls, the site became dual listed. ${ }^{126}$ In spite of its mixed inscription, conflicting agendas have resulted in governance challenges and funding difficulties. ${ }^{127}$ For example, the Anangu continue to be poorly represented in the tourism aspects of the Park, and while a majority of the Park's Board of Management are Anangu, control over the Park remains an issue. ${ }^{128}$ This is due to powerful external and internal influences, namely the tourism industry and Australian Government politics and processes, which exert significant pressure. ${ }^{129}$

These power struggles are exemplified by the debate concerning the proposed ban on the climbing of Uluru. The Anangu people have requested for decades that the climbing of Uluru cease due to "the rock's" cultural significance as a sacred site. ${ }^{130}$ The path followed by the climb represents an important dreaming track, part of Anangu "lore" (Tjukurpa) and culture. ${ }^{131}$ The proposed ban has

122 M. Baird, 'The Breath..., p. 328.

123 Ibidem, pp. 328-329.

124 C. Ricci, Between a Rock and a Sacred Place, "Sydney Morning Herald", 20 July 2009, http://www. smh.com.au/national/education/between-a-rock-and-a-sacred-place-20090716-dmoa.html [accessed: 31.10.2017].

125 Ibidem.

126 Other older inscriptions that are now regarded as mixed sites include the Tasmanian Wilderness in Australia, the Bandiagara site in Mali, the Uluru-Kata Tjuta National Park, and the Kakadu National Park in Australia (J. Blake, op. cit., pp. 132, 133). See also J. Jokilehto, op. cit., p. 229.

127 M. Riphagen, Why Is It Still Possible to Climb Uluru?, "The Conversation", 12 May 2016, https://theconversation.com/why-is-it-still-possible-to-climb-ulu-u-r-u-u-58729 [accessed: 31.10.2017].

128 See especially M. Adams, Pukulpa Pitjama Ananguku Ngurakutu - Welcome to Anangu Land: World Heritage at Uluru-Kata Tjuta National Park [Faculty of Science paper], University of Wollongong 2014, p. 19; see e.g. M. Riphagen, op. cit.

129 M. Adams, op. cit., p. 19.

130 Ibidem; see also M. Riphagen, op. cit.

131 See generally M. Riphagen, op. cit.; see also C. Ricci, op. cit. 
enlivened the debate concerning ownership of "the rock", highlighting tensions between the various characterizations of heritage. ${ }^{132} \mathrm{~A}$ common response is that "the rock" is not the property of anyone, and as such all individuals possess the right to climb it. ${ }^{133}$ The Grand Canyon is cited as a comparable example in this regard of a site considered culturally significant but which does not contain climbing restrictions. ${ }^{134}$ Former Federal Opposition Environment spokesman Greg Hunt also opposes the climbing ban, stating that this would end "one of the great tourism experiences [of] Australia". ${ }^{135} \mathrm{He}$ added that this would translate to "privileging the rights of traditional owners at the expense of what is a human right to enjoy the world's natural resources", which would demonstrate "a profound disrespect for the sacredness of World Heritage sites for all humanity".136

Here it can be seen how it happens that in some ways a WHL designation effectively re-positions Indigenous peoples outside of their systems of authority, and positions the State, landowners, and tourism industry as the mediators of Indigenous heritage. ${ }^{137}$ In this instance, the promotion of tourism and universalist principles and values, including the legitimization of national identities, subverted and suppressed the rights of the Anangu to control their cultural heritage..$^{138}$ Such a situation is in violation of Article 15 of the ICESCR and is inconsistent with Articles 3, 31, and 18 of the UNDRIP, as these practices limit Anangu participation in negotiating, controlling, and managing their heritage. This is further exemplified by the Australian Government's failure to facilitate and encourage the full participation of the Anangu in decision-making processes in matters which affect their rights, ${ }^{139}$ including control over the Park's management and operation practices, ${ }^{140}$ particularly with respect to the proposed climb ban. This further highlights that the WHL and protection practices contain a powerful political and colonial dimension that undermines rather than strengthens Indigenous rights, identity, practices, and knowledge systems, including management and control of their cultural heritage. ${ }^{141}$ Sadly, a discussion of the Tongariro National Park below suggests that this is a common theme underlying mixed WHL sites.

\footnotetext{
132 See generally M. Riphagen, op. cit.; see also C. Ricci, op. cit.

133 C. Ricci, op. cit.

134 Ibidem.

135 Ibidem.

136 Ibidem.

137 M. Baird, 'The Breath..., p. 330.

138 Ibidem, p. 331.

UNDRIP, op. cit., Article 18; see also UNESCO Operational Guidelines..., op. cit., para. 123.

140 UNDRIP, op. cit., Article 31.

141 W. Logan, op. cit., p. 231.
} 


\section{DEBUTS}

Marijke Bassani

\section{Tongariro National Park}

The Tongariro National Park is located in the central North Island of New Zealand, of which the Ngati Tuwharetoa and Ngati Rangi (Maori) peoples are the traditional owners. ${ }^{142}$ In 1887 the Chief of Ngati Tuwharetoa, Horonuku Te Heuheu Tukino IV, "gifted" Tongariro to the Crown, becoming in 1894 New Zealand's first national park. ${ }^{143}$ The Park was listed as a natural World Heritage site in 1990, and in 1993 became the first dual listed site. ${ }^{144}$ Today, the "gift" of Tongariro is promoted throughout the Park management literature, as well as national history, as a model of good will and governance and as such has "entered into national folklore and [...] acquired [...] iconic significance". ${ }^{145}$ However, the "gift" is understood differently by Maori and, more importantly the Ngati Tuwharetoa and Ngati Rangi, who view the "gift" as a historic exchange that requires reciprocity and protection of the region - a promise that, as a result of tourism, has been violated. ${ }^{146}$ This again exemplifies how the colonial history of a World Heritage site is often silenced and presented for an international audience, devoid of the larger political issues concerning Indigenous sovereignty, autonomy, and control of identity. ${ }^{147}$

Additionally, the Park's current management problematically places emphasis on protection of the site's natural heritage, as Park Managers are required to adhere to the provisions of the National Parks Act 1980 (NZ), which privileges the Park's natural values and the needs of the public. ${ }^{148}$ Although Maori interests are included in the Park's management philosophy, they are not a priority. ${ }^{149}$ For example, the Park includes privately owned commercial ski areas that encroach on various sacred sites that hold cultural significance. ${ }^{150}$ Although Maori peoples voiced concerns about tourist access to these parts of the Park, indicating that such would be a violation of traditional law (Taonga), the commercial ski area was expanded with the addition of chair lifts and snow making operations. ${ }^{151}$ This again demonstrates how the rights and interests of States, tourism industries, and landowners are, in relation to the heritage listed, often privileged and Indigenous interests are further marginalized during the process by which States seek to "protect" Indige-

\footnotetext{
142 M. Baird, 'The Breath..., p. 327.

143 Ibidem.

144 Ibidem.

145 Ibidem, p. 331.

146 Ibidem.

147 Ibidem, p. 337.

148 Ibidem.

149 Ibidem.

150 Ibidem.

151 Ibidem, p. 333.
} 
nous heritage..$^{152}$ Indeed, it appears that "protection" as such is more about power and control than respect.

Similar to Uluru-Kata Tjuta National Park, such practices leave little or no margin for effective Maori participation in negotiating and managing their heritage, and is incompatible with Article 15 of the ICESCR and Articles 3, 18, and 31 of the UNDRIP. The New Zealand Government's failure to implement Maori philosophies in the Park's management, including preventing the expansion of the ski area onto sacred sites, exemplifies this. Furthermore, the decision-making power and processes concerning the Park's management rest in the hands of a few, which precludes Maori participation and exacerbates their inability to determine measures required to protect their heritage. ${ }^{153}$ These inequities in the control and protection of World Heritage reveal how Indigenous voices are excluded, and thus Indigenous peoples are precluded from asserting their social and political authority over their heritage. ${ }^{154}$

Such practices reinforce the use by the State of WHL for economic, identity, and nation-building purposes. ${ }^{155}$ This has negative consequences for the cultural identity of Maoris, as these appropriated and essentialized meanings of their heritage result in the exclusion of Maori voices. ${ }^{156}$ Again, the observation here is that legacies of colonial policies are embedded in contemporary heritage practices, as is manifested in the omission of Maori voices in the stories of the site. ${ }^{157}$ Consequently, Indigenous peoples are challenged to make their claims within a system that is incompatible with their custodial responsibilities, practices, and customary laws. ${ }^{158}$ In the process, as was the case here, outsiders are able to construct and reinterpret histories that naturalize the constructs of the Indigenous heritage, appropriate meanings of the land, and silence the historical struggles. ${ }^{159}$

\section{Recommendations}

As the two cases above illustrate, granting a State power over the listing of heritage necessarily diminishes the power of Indigenous peoples over their own heritage. ${ }^{160}$ While the State has an obligation to ensure full and effective participation ${ }^{161}$

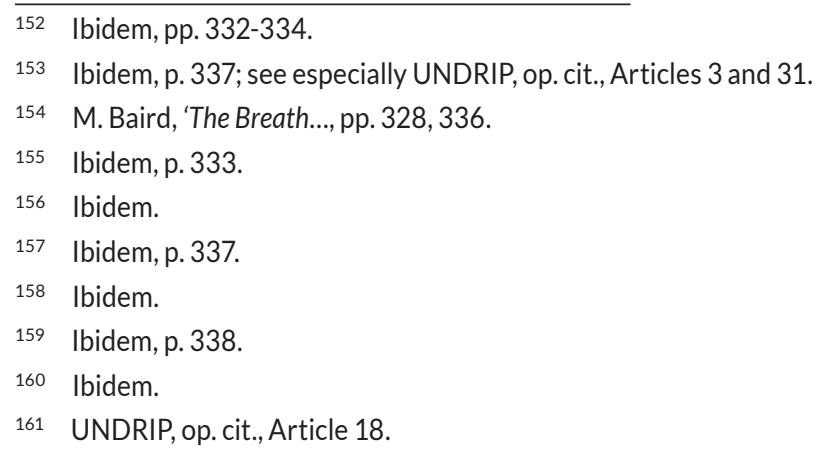




\section{DEBUTS}

Marijke Bassani

of Indigenous peoples in managing their heritage, such protection has usually resulted in dispossession for the Indigenous group who created the culture. ${ }^{162}$ Both WHL sites discussed above highlight that State interests, particularly in relation to resource management and allocation, lie at the very core of heritage protection and as such, heritage protection continues to have a powerful political and colonial dimension. ${ }^{163}$ Article 6 of the 1972 Convention highlights this, as it treats Indigenous sovereignty unfairly vis-à-vis State sovereignty by affirming respect for "the sovereignty of the State on whose territory the cultural and natural heritage [...] is situated". ${ }^{164}$

In order to disarm these European colonial State-centric structures, we must decolonize ${ }^{165}$ the international cultural heritage framework by locating and acknowledging how current heritage theories and practices, including the WHL, operate through systems of colonial power and exclusion. ${ }^{166}$ One must begin by acknowledging that while the universalist principles underpinning international cultural heritage law play an important role in preserving and protecting the cultural heritage of mankind, they do so in a way that undermines Indigenous values, rights, identities, practices, knowledge systems, and claims to heritage. ${ }^{167}$ Consequently, "cultural heritage" as it currently stands is incompatible with "Indigenous heritage", as it fails to recognize that the tangible and intangible aspects of cultural heritage are constitutive of Indigenous identity, and that without acknowledgement of this reality the cultural survival of Indigenous peoples and their heritage will be jeopardized. ${ }^{168}$

Therefore, a human rights-based approach - based on Article 15 of the ICESCR and Articles 3, 18, and 31 of the UNDRIP - to the protection and preservation of cultural heritage, including WHL sites, is necessary in order to invoke international standards for Indigenous peoples' rights and allow for cultural heritage to be used as a vehicle in strengthening the protection of Indigenous identities, practices, knowledge systems, and claims to heritage. ${ }^{169}$ Importantly, the protection and preservation of cultural heritage in a human rights context not only safeguards specific objects or manifestations, but also protects the relationship of Indigenous peoples' to their cultural heritage, including the social structures and

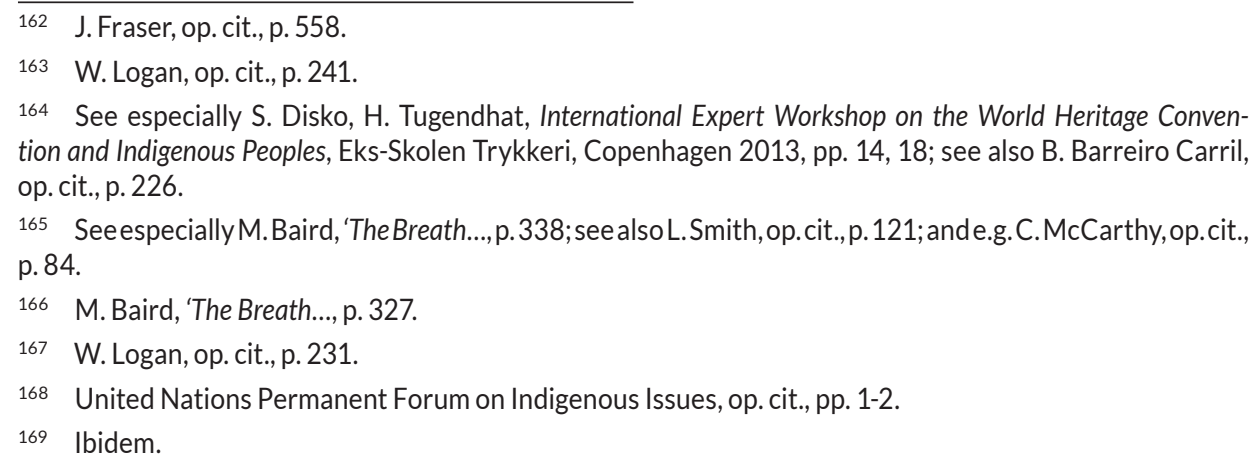
tion and Indigenous Peoples, Eks-Skolen Trykkeri, Copenhagen 2013, pp. 14, 18; see also B. Barreiro Carril, op. cit., p. 226.

165 SeeespeciallyM.Baird,'TheBreath...,p.338; seealso L.Smith,op.cit.,p.121; and e.g.C.McCarthy,op.cit., p. 84.

166 M. Baird, 'The Breath..., p. 327.

167 W. Logan, op. cit., p. 231.

168 United Nations Permanent Forum on Indigenous Issues, op. cit., pp. 1-2.

169 Ibidem. 
cultural processes that underlie this relationship. ${ }^{170}$ Thus, in an Indigenous context a human rights-based approach allows Indigenous peoples to determine the identification, inscription, and management of their heritage, including selection of the values proposed through their own decision-making processes. ${ }^{171}$ This aligns with Article 15 of the ICESCR and Articles 3, 18, and 31 of the UNDRIP, which recognize the right of Indigenous peoples to determine and participate in decisions concerning the protection and preservation of their heritage.

Together these rights provide a platform for advocating the centralization of Indigenous human rights as both "a theme in heritage identification and a set of policy principles underlying heritage protection processes". ${ }^{172}$ This will ensure that heritage practices are Indigenous-driven, and thus consistent with international legal norms protecting Indigenous rights. ${ }^{173}$ Such an approach is crucial since it transforms heritage practices from disempowering to empowering Indigenous peoples. Accordingly, the ability of Indigenous peoples to control their own cultural heritage and identity is strengthened, and this lends support to Indigenous cultural claims, providing the foundation upon which Indigenous political claims for autonomy are built. ${ }^{174}$ Despite this, one must acknowledge that a human rights-based approach will not erase the inherent limitations of the WHL when it comes to protecting Indigenous heritage, both tangible and intangible. The fundamental flaw concerns the practical reality that not all relevant Indigenous heritage can ever be protected under the 1972 Convention. However, establishing heritage practices that are Indigenous-driven and consistent with international legal norms protecting Indigenous rights, ensures that Indigenous peoples whose heritage is listed or nominated for inscription are provided every opportunity to determine and participate in decisions concerning the protection and preservation of their heritage.

\section{Conclusions}

From a human rights-based perspective, the inscription of Indigenous heritage to the WHL rarely, if ever, benefits Indigenous peoples. ${ }^{175}$ As such has broader implications for Indigenous peoples who consider cultural heritage - both tangible and intangible - as constitutive elements that lie at the very core of their Indigenous identity. ${ }^{176}$ For Indigenous peoples, the distinction between both elements is impossible, since it reflects an artificial distinction between heart, mind, and the envi-

\footnotetext{
170 S. Maus, op. cit., p. 709.

171 Ibidem.

172 J. Fraser, op. cit., p. 561.

173 See especially B. Barreiro Carril, op. cit., p. 224; see also M. Baird, 'The Breath..., p. 339.

174 B. Barreiro Carril, op. cit., p. 227.

175 Ibidem, p. 225.

176 K. Carpenter, S. Katyal, A. Riley, op. cit., p. 1028.
} 


\section{DEBUTS}

Marijke Bassani

ronment - a viewpoint that is indeed incompatible with their philosophy ${ }^{177}$ Unfortunately, the current international cultural heritage protection paradigm endorses a European colonial State-centric view that struggles to reconcile both aspects of heritage, resulting in prioritization of the "natural" values of heritage over its "cultural" values. ${ }^{178}$ Consequently, the protection currently afforded to Indigenous heritage is overly bureaucratized, piecemeal, and inadequate when it comes to accounting for Indigenous understandings of cultural heritage. ${ }^{179}$ This state of affairs is not only incompatible with Articles 3, 18, and 31 of the UNDRIP and Article 15 of the ICESCR, but is also inconsistent with the holistic worldview of Indigenous peoples and inevitably results in different standards of protection for different elements of their heritage. ${ }^{180}$ As has been demonstrated in the analysed cases, this has negative consequences for Indigenous peoples, whose rights, identities, histories, practices, and knowledge systems are further marginalized during the process by which States seek to "protect" their cultural heritage, while in fact protecting the State's own version. ${ }^{181}$

\section{References}

Adams M., Pukulpa Pitjama Ananguku Ngurakutu - Welcome to Anangu Land: World Heritage at Uluru-Kata Tjuta National Park [Faculty of Science paper], University of Wollongong 2014.

African Commission on Human and Peoples' Rights, Centre for Minority Rights Development (Kenya) and Minority Rights Group International on behalf of Endorois Welfare Council v. Kenya, Judgment of 25 November 2009.

Baird M., 'The Breath of the Mountain Is My Heart': Indigenous Cultural Landscapes and the Politics of Heritage, "International Journal of Heritage Studies" 2012, Vol. 19(4).

Baird M., The Politics of Place: Heritage, Identity, and the Epistemologies of Cultural Landscapes [Ph.D. diss.], University of Oregon 2009.

Banks J., McGee C. (eds.), Multicultural Education: Issues and Perspectives, Allyn \& Bacon, Boston 1989.

Barreiro Carril B., Indigenous Peoples' Participation in Decision-Making in the Context of World Heritage Sites: How International Human Rights Law Can Help?, "The Historic Environment: Policy \& Practice" 2016, Vol. 7(2-3).

Battiste M., Henderson J.Y. (eds.), Protecting Indigenous Knowledge and Heritage: A Global Challenge, Purich Publishing Ltd, Saskatoon 2000.

Blake J., International Cultural Heritage Law, Oxford University Press, Oxford 2015.

Carpenter K., Katyal S., Riley A., In Defense of Property, "Yale Law Journal” 2009, Vol. 118(5).

$177 \quad$ A. Yupsanis, op. cit., p. 337.

178 J. Blake, op. cit., pp. 20, 152.

179 Ibidem, p. 20.

180 A. Yupsanis, op. cit., p. 337.

181 M. Baird, 'The Breath..., p. 332-334. 
Chapman T., Corroboree Shield: A Comparative Historical Analysis of (The Lack of) International, National and State Level Indigenous Cultural Heritage Protection, "Macquarie Journal of International and Comparative Environmental Law" 2008, Vol. 5(1).

Convention Concerning the Protection of the World Cultural and Natural Heritage, 16 November 1972, 1037 UNTS 151.

Convention for the Protection of Cultural Property in the Event of Armed Conflict, 14 May 1954, 249 UNTS 240.

Convention for the Safeguarding of Intangible Cultural Heritage, 17 October 2003, 2368 UNTS 1.

Convention on the Means of Prohibiting and Preventing the Illicit Import, Export and Transfer of Ownership of Cultural Property, 14 November 1970, 823 UNTS 231.

Convention on the Protection and Promotion of the Diversity of Cultural Expressions, 20 October 2005, 2240 UNTS 346.

Daes E.-I., Protection of the Heritage of Indigenous People, OHCHR, New York 1997.

Disko S., The 39th Session of the World Heritage Committee, in: D. Vinding, C. Mikkelsen (eds.), The Indigenous World 2016, Transaction Publishers, Copenhagen 2016.

Disko S., Tugendhat H., International Expert Workshop on the World Heritage Convention and Indigenous Peoples, Eks-Skolen Trykkeri, Copenhagen 2013.

Foucault M., The Subject and Power, in: H. Dreyfus, P. Rabinow (eds.), Michel Foucault: Beyond Structuralism and Hermeneutics, University of Chicago Press, Chicago 1983.

Fraser J., Cultural Heritage in Transit: Intangible Rights as Human Rights, "Human Rights Quarterly" 2015, Vol. 37(2).

Habermas J., Some Question Concerning the Theory of Power: Foucault Again, in: M. Kelly (ed.), Critique and Power: Recasting the Foucault/Habermas Debate, Massachusetts Institute of Technology Press, Cambridge, MA 1994.

Harrington J., "Being Here": Heritage, Belonging and Place Making: A Study of Community and Identity Formation at Avebury (England), Magnetic Island (Australia) and Ayutthaya (Thailand) [Ph.D. diss.], James Cook University 2004.

Harrison R. (ed.), Understanding the Politics of Heritage, Manchester University Press, Manchester 2009.

Hill R. et al., Empowering Indigenous Peoples' Biocultural Diversity Through World Heritage Cultural Landscapes: A Case Study from the Australian Humid Tropical Forests, "International Journal of Heritage Studies" 2011, Vol. 17(6).

Hunt J., NSW Cultural Heritage Reform: Does the Proposed Model Reflect the United Nations Declaration on the Rights of Indigenous Peoples?, "Indigenous Law Bulletin" 2014, Vol. 8(10).

International Covenant on Civil and Political Rights, 16 December 1966, 999 UNTS 171.

International Covenant on Economic, Social and Cultural Rights, 16 December 1966, 993 UNTS 3.

Jokilehto J., Human Rights and Cultural Heritage. Observations on the Recognition of Human Rights in the International Doctrine, "International Journal of Heritage Studies" 2012, Vol. 18(3).

Keesing R., Theories of Culture, "Annual Review of Anthropology" 1974, Vol. 3(1).

Lederach J., Preparing for Peace: Conflict Transformation Across Cultures, Syracuse University Press, Syracuse 1995.

Lixinski L., Intangible Cultural Heritage in International Law, Oxford University Press, Oxford 2013. 


\section{DEBUTS}

Marijke Bassani

Logan W., Cultural Diversity, Cultural Heritage and Human Rights: Towards Heritage Management as Human Rights-Based Cultural Practice, "International Journal of Heritage Studies" 2012, Vol. 18(3).

Marx K., Engels F., The German Ideology, transl. C.J. Arthur, International Publishers, New York 1970.

Maus S., Hand in Hand Against Climate Change: Cultural Human Rights and the Protection of Cultural Heritage, "Cambridge Review of International Affairs" 2014, Vol. 27(4).

McCarthy C., Museums and Māori: Heritage Professionals, Indigenous Collections, Current Practice, Left Coast Press, Wellington 2011.

National Parks Act 1980, 17 December 1980, Public Act, 1980, No. 66.

Parsons T., Essays in Sociological Theory, Pure and Applied, Free Press, New York 1949.

Pepper R., Duxson S., Not Plants or Animals: The Protection of Indigenous Cultural Heritage in NSW, "Judicial Officers Bulletin" 2014, Vol. 26(9).

Ricci C., Between a Rock and a Sacred Place, "Sydney Morning Herald", 20 July 2009, http://www.smh.com.au/national/education/between-a-rock-and-a-sacred-place20090716-dmoa.html [accessed: 31.10.2017].

Riphagen M., Why Is It Still Possible to Climb Uluru?, "The Conversation”, 12 May 2016, https:// theconversation.com/why-is-it-still-possible-to-climb-ulu-u-r-u-u-58729 [accessed: 31.10.2017].

Sissons J., First Peoples: Indigenous Cultures and Their Futures, Reaktion Press, London 2005.

Smith L., The Uses of Heritage, Routledge, London 2006.

Texas A \& M University, Culture, 2016, https://www.tamu.edu/faculty/choudhury/culture. html [accessed: 31.10.2017].

UN Declaration on the Rights of Indigenous Peoples, 13 September 2007, UN Doc. A/RES/61/295 (2007).

UNESCO Declaration on the Principles of International Cultural Cooperation, 16 November 1966, UNESCO Doc. 28 C/Res 5.61 (1966).

UNESCO Operational Guidelines for the Implementation of the World Heritage Convention, 8 July 2015, UNESCO Doc. WHC.15/01 (2015).

UNESCO Universal Declaration on Cultural Diversity, 2 November 2001, UNESCO Doc. 31C/Res. (2001).

United Nations Permanent Forum on Indigenous Issues, Who Are Indigenous Peoples?, Fact Sheet No. 3.

Universal Declaration of Human Rights, 10 December 1948, UNGA Res 217 A(III).

University of Minnesota. The Center for Advanced Research on Language Acquisition, What Is Culture?, 2014, http://carla.umn.edu/culture/definitions.html [accessed: 31.10.2017].

US Chapter of the Association of Critical Heritage Studies, Welcome to the US Chapter of ACHS, 2013, http://achsus.umbc.edu [accessed: 31.10.2017].

Winter T., Beyond Eurocentrism? Heritage Conservation and the Politics of Difference, "International Journal of Heritage Studies" 2014, Vol. 20(2).

Yupsanis A., Cultural Property Aspects in International Law: The Case of the (Still) Inadequate Safeguarding of Indigenous Peoples' (Tangible) Cultural Heritage, "Netherlands International Law Review" 2011, Vol. 58(3). 